DOI: 10.33766/2524-0323.90.40-49

УДК 343.2.01

I. В. Козич,

кандидат юридичних наук, доцент, доцент кафедри кримінального права навчально-наукового юридичного інституту

ДВНЗ «Прикарпатський національний університет імені В. Стефаника»

(м. Івано-Франківськ, Україн e-mail: kozych.igor.df@gmail.com

iDhttps:/ / orcid.org/0000-0002-8746-1154

\title{
МЕТОДИ ДОСЛІДЖЕННЯ КРИМІНАЛЬНО-ПРАВОВОЇ ПОЛІТИКИ ТА ЇЇ ФУНКЩЙ
}

Будь-яка наукова розвідка в галузі юриспруденщії зазвичай розпочинається із формулювання та окреслення наукової проблеми, яка підлягає розв'язанню в процесі дослідження. Проте самого розуміння проблеми, визначення їі об'єкту та предмету, явно недостатньо, адже кожен науковець, усвідомивши ці питання та визначивши для себе відповідну мету й завдання, стикається з необхідністю вибору методів дослідження, які, на його погляд, є найбілыш ефективними для вирішення того чи іншого завдання. Це обов'язкова складова сучасного наукового дослідження, яка визначає подалыші способи отримання емпіричного матеріалу та його обробки для досягнення виправданих та науково обгрунтованих результатів.

У статті автор розглядає особливості застосування загальнонаукових, групових та спеціально-наукових методів, виходячи зі специфіки дослідження кримінально-правової політики та їі функцій.

Ключові слова: політика у сфері боротьби зі злочинністю, кримінально-правова політика, функції політики у сфері боротьби зі злочинністю, функції кримінально-правової політики, методи наукового дослідження.

Постановка проблеми. У вітчизняній юриспруденщії методологію юридичної науки складає система підходів, методів і способів наукового дослідження, а також теоретичні засади їх використання. Автори юридичної енциклопедії виділяють три групи методів дослідження в правовій сфері. До першої групи відносяться матеріалістичний та ідеалістичний, діалектичний та метафізичний підходи до вирішення наукових завдань. До другої - загальнонаукові методи, які використовуються фактично в усіх або в білышості наук (структурний, функціональний, сходження від абстрактного до конкретного, аналіз, синтез). Також, що є особливо важливим для даного дослідження, до цієї ж групи належать т. зв. групові методи, які застосовуються в певних групах наук. I, нарешті, до третьої групи відносяться методи, прийнятні для дослідження в межах конкретної науки, по-іншому - спеціально-наукові методи [1, с. 618]. За іншим критерієм, методи поділяють на емпіричні (ті, що спрямовані на отримання вхідних даних) та теоретичні (які базуються на всебічному вивченні, поясненні, узагальненні зібраних даних і вироблення на цій основі певних нових висновків, понять, конщепщій, прогнозів тощо).

Повністю підтримуючи вказані енциклопедичні класифікаційні підходи до методології правових та кримінально-правових досліджень, варто зазначити, що вони,

(C) Козич I. В., 2020 
звичайно, повинні бути застосовані до досліджень підсистем політики у сфері боротьби зі злочинністю, але з відповідними особливостями, зумовленими специфікою кримінально-правової політики та ї̈ функцій як досліджуваного явища.

Аналіз останніх досліджень і публікацій. Питання методології, власне, кримінально-правових досліджень достатньо розглянуте в спеціалізованій літературі, зокрема в працях Ю. В. Бауліна, В. І. Борисова, Л. М. Демидової, О. О. Дудорова, М. І. Колоса, В. О. Навроцького, М. І. Панова, О. П. Рябчинської, В. Я. Тація, В. О. Тулякова та ін. Методи дослідження державних політик теж отримали своє доктринальне монографічне обгрунтування [2]. Однак питання дослідження особливостей наукових методів пізнання кримінально-правової політики та ії функцій залишається відкритим.

Формулювання цілей. Метою даної статті виступає висвітлення особливостей застосування загальноприйнятих методів наукових досліджень щодо кримінальноправової політики та ї̈ функцій

Виклад основного матеріалу. Дослідження питань кримінально-правової політики (як складової такого напрямку державної політики, як політика у сфері протидії злочинності) володіє низкою специфічних характеристик, які вимагають особливого наукового погляду, як зі сторони визначення предмета, об'єкта, мети та завдань дослідження, так і з методологічних позищій.

По-перше, як слушно зазначають дослідники методології державної політики, у літературі відбулося розмежування між поняттями «дослідження політики» й «аналіз політики» [2, с. 15-16]. Дослідження стосується власне політики (та ї̈ напрямкі - I. K.) як соціально-державного феномену. Ці дослідження політики, які здебільшого проводяться академічними й університетськими вченими, належать до метаполітики й спрямовані на розуміння процесів державної політики. Водночас аналіз політики, яким займаються урядові та спеціальні політичні комітети, загалом спрямований на планування реальної політики. Перше $є$ концептуальним пояснюючим описом у порівнянні з директивним характером другого [2, с. 16]. Саме з цих міркувань, зазвичай, мова йде про дослідження кримінально-правової політики та їі функцій, хоча для розкриття тих чи інших взаємодій функцій та їхнього взаємовпливу чи взаємодій між собою не виключеним є застосування результатів аналізу політики.

По-друге, поширений для абсолютної більшості кримінально-правових досліджень [3; 4 та ін.] догматичний метод, даючи хороші результати при аналізі чинного кримінального законодавства та варіантів його удосконалення, виявляється майже не дієвим для досліджень загальнофункціональних особливостей будь-якого напрямку державної політики, у т.ч кримінально-правової як підсистеми політики у сфері протидії злочинності. Дійсно, в основу цього методу покладені застосовні до конкретної аналізованої кримінально-правової норми закони формальної логіки, а також сучасні досягнення у сфері граматичного тлумачення нормативно-правових актів. Він чудовий для усвідомлення та роз'яснення тексту кримінально-правової норми, тлумачення іiі змісту в контексті правильного нормозастосування; результативним буде і для вирішення питань удосконалення та систематизації законодавства. Однак дослідження загальнонаукових та теоретико-прикладних проблем кримінально-правової політики вкрай рідко стикається з проблемами вивчення логіко-граматичного змісту конкретних норм, хіба що з питань окреслення якихось тенденщій чи розвитку окремих інститутів. Інша річ - вивчення конкретних загальних чи спеціальних сфер кри- 
мінально-правової політики. Наприклад, цей метод активно використовувався в попередніх дослідженнях автора, при вивченні кримінально-правової політики у сфері протидії злочинам, що вчиняються із застосуванням насильства [5].

По-третє, кримінально-правова політика, з огляду на свою природу, вимагає міждисциплінарного підходу. Будучи комплексним явищем, яке втілює в собі досягнення, фактично, усіх наук кримінально-правового циклу, вона хоч-не-хоч базується й на надбаннях багатьох інших наук, зокрема таких, як політологія, соціологія, історія політико-правових учень, філософія, державне управління тощо. І саме через це iї дослідження не може не враховувати, окрім широкого емпіричного матеріалу вказаних наук, ще і специфічної методології, яка виявляється вкрай необхідною для дослідження ефективної реалізації функцій кримінально-правової політики.

По-четверте, існуючі на сьогодні доктринальні дослідження кримінально-правової політики дали певні, досить глибокі, уявлення щодо завдань, принщипів, суб'єктів, джерел, типів та інших ії складових. Однак жоден дослідник не аналізував кримінально-правову політику як самоорганізовану, постійно діючу систему, яка має власні функціі, які, зрештою, і вирішують поставлені перед нею завдання. Через те варто враховувати й необхідність використання методології насамперед щодо вивчення функціонування систем, у тому числі і в політичній сфері, адже ніхто не піддає сумніву той факт, що політика у сфері протидії злочинності являє собою певну функціональну систему, яка спрямована на убезпечення суспільства шляхом мінімізації злочинності.

I п'ятий, надзвичайно важливий, організаиійно-методологічний аспект. Для досягнення мети та розв'язання завдань дослідження слід обирати метод або їх поєднання, які б дали змогу отримувати відповідні знання чи результати ${ }^{1}$. Наприклад, як стверджують дослідники методології вивчення державних політик, не можна дослідити державну політику у сфері оподаткування населення на підставі публікацій та повідомлень у ЗМІ чи заяв партійних лідерів та громадських активістів - тут потрібно використовувати сполучення методів (кількісні, якісні, системний, порівняльний тощо), придатних до аналізу та виміру стану загальної соціально-економічної ситуації в країні, спроможності/неспроможності бюджету, ринку пращі, якості й тривалості життя людей [2, с. 20]. Отже, для вивчення окремих аспектів функцій кримінально-правової політики застосування релевантних методів є єдино можливим варіантом для отримання результатів, бо застосування інших приведе до їх спотворення. 3 іншого боку, постійно слід враховувати той момент, що кожен дослідник займає певну наукову позищію, має певну базу знань, умінь та навичок, що індивідуалізує дослідження питань функцій кримінально-правової політики, адже на таку складну систему як політика у сфері протидії злочинності можна дивитися з багатьох точок зору, що веде не лише до диференщіювання об'єкту та предмету дослі-

\footnotetext{
1 Л. М. Демидова вважає, що ефективний вибір методології повинен базуватися на оптимальності й композиційності в організації пізнавального процесу, які досягаються шляхом формулювання і впровадження домінуючої ідеї, яка є стратегічною і впливає на вибір методологічного інструментарію й межі його використання. Оптимальний композиційний підхід сприяє всебічному кримінально-правовому дослідженню і віддзеркалюється упорядкованою структурою наукової роботи та ії змістом [4]
} 
джень, а й до застосування дослідниками різноманітних методів. Звичайно, результати внаслідок цього можуть бути дещо відмінними. Однак це завжди залишає поле для подалыших дискусій, спрямованих на побудову ефективно функціонуючої моделі кримінально-правової політики, яка буде виконувати своє основне призначення: убезпечення суспільства шляхом мінімізащії злочинності та запобігання йй кримінально-правовими засобами. Отож при виборі методів дослідження функцій кримінально-правової політики, слід виходити із загальнонаукової методології, з урахуванням вищеназваної специфіки даного дослідження.

Як слушно зауважив М. І. Панов, наука кримінального права, як і кожна юридична наука, не створює й не може створювати деякої «самостійної» чи «відокремленої» методології. Вона має спиратися на загальнотеоретичні положення методології теорії пізнання як філософської науки (чи теорії пізнання як їі розділу), використовувати їх із метою здійснення досліджень свого власного і специфічного об'єкта (предмета) пізнання [6]. Тому не викликає сумнівів застосування при проведенні будь-якого дослідження, у т. ч. і даного, використання загальнологічних методів аналізу, синтезу, узагальнення, індукції та дедукцій, адже при вивченні функціонування кримінально-правової політики необхідним, уявляється, є виділення (аналіз) кожної іï функції, а також вивчення їх реалізації в притаманних для них взаємозв' язках та взаємовпливах (синтез та узагальнення).

На основі дослідження якогось окремо взятого типового прикладу реалізації однієї чи декількох функцій кримінально-правової політики можна робити висновок про постійне, таке ж саме функціонування всієї системи (індукція). Специфіка застосування даного методу щодо вивчення функцій кримінально-правової політики, таким чином, полягає в тому, що на основі існуючих фактів чи результатів реалізації кримінально-правової політики, можна зробити аргументоване припущення про те, як це буде працювати взагалі, при інших вихідних даних і в іншій ситуащіі (для прикладу, при зміні керівнищтва держави чи навіть зміні в державній політищі, зумовленій, зокрема, переходом влади до іншої політичної сили). Такий висновок випливає з індуктивних закономірностей: в основі всіх подій та взаємозв 'язків у сфері протидії злочинності повинна лежати постійно функціонуюча модель кримінально-правової політики.

Метод дедукції (сходження від загального до конкретного) в сукупності 3, наприклад, історико-правовим методом, є незамінним при вивченні становлення та розвитку політико-правових учень про кримінально-правову політику та їі функціонування. Не дарма видатні мислителі минулого нерідко розглядали політику у сфері протидії злочинності як складову всієї державної політики. Досліджуючи в такий спосіб особливості функціонування державної політики (загальне) й описуючи iї функції, вони, зазвичай, не виділяли окремо функції кримінально-правової політики (конкретне). Однак їхні судження щодо політики в цілому будуть справедливими і для їі напрямків, у даному випадку - політики у сфері протидії злочинності, адже якщо якесь твердження є справедливим для всієї системи, то воно буде справджуватися і для їі частини - саме в цьому полягає сутність дедуктивного методу.

Серед особливих методів, які мають свою специфіку при дослідженні функцій кримінально-правової політики, чільне місце посідає метод структурно-фрункиіонального аналізу. Як вказує В. С. Горбань, в історії політико-правової думки першим правознавцем, хто використовував цей гносеологічний принцип у якості основного 
у своїй науково-дослідницькій програмі, був Срінг, який обгрунтував його застосування до аналізу права [7]. 3 позицій вивчення функцій кримінально-правової політики, цей метод безапеляційно є одним із основних, оскільки саме за його допомогою можна встановити роль і значення окремих функцій у роботі всієї системи кримінально-правової політики, яка, своєю чергою, є підсистемою політики у сфері протидії злочинності.

А. В. Пехник слушно зауважив, що вивчення політики та ії проявів вимагає звернення і до теорії систем, тому що процеси управління й політики невіддільні від принципів функціонування систем управління й політичних систем [8, с. 423]. Виходячи $з$ того, що кримінально-правова політика являє собою певну систему, то не викликає сумнівів і застосування досягнень теорії систем та їі методології, основою якої є системний nidxid (системний метод, метод системного аналізу тощо). У багатьох дослідженнях науковці в загальному цей метод представляють як такий, при якому досліджувані явища розглядаються як частини або елементи єдиного, цілісного утворення - системи. Слід також враховувати, що політична система як функціонуючий організм (як будь-яка система відповідно до теорії систем) $є$ результатом погодженої дії двох механізмів - управління й самоорганізації, що також підтверджує необхідність застосування вказаного методу при вивченні кримінально-правової політики та її складових.

Вивчення за допомогою вищеназваних методів структурно-функціонального та системного аналізу зумовлює використання ще й методів моделювання та прогнозування. Щодо цього П. Л. Фріс вказує, що модель являє собою спрощене відображення реальності - це менш детальне, менш складне, менш докладне відтворення реально існуючого об'єкта або феномена. Учений вважає, що коли ми говоримо про моделювання такого соціального феномену, як злочинність, модель, по суті, являє собою не просто спрощення реальності, а відображення реальності через призму певного теоретичного підходу або думки експерта. У цьому сенсі моделювання можна розглядати як білыш точне і формалізоване (у порівнянні з традищійною текстуальною формою) описання теоретичної конщепщії, висновків експертного аналізу, результатів первинного дослідження. Класичним результатом застосування методу моделювання є розроблення прогнозу. На підставі наведеного П. Л. Фріс резюмує: «прогнозування можна вважати одним із найбілыш цінних інструментаріїв моделювання політики у сфері боротьби зі злочинністю» [9, с. 606]. Щоправда, учений веде мову про моделювання у якості т.зв. кримінологічної експертизи законопроєкту (у пізніших публікаціях - «моделювання кримінального закону» [напр. 10]), оскільки дає відповідь на питання про можливі негативні наслідки його застосування, про його ефективність. Цілком погоджуючись із цим положенням, варто зазначити, що в даному дослідженні, крім питань конкретної реалізації нормотворчої функції (в аспекті вказаної експертизи), метод моделювання застосовується і для побудови моделі кримінально-правової політики, яка відображає іï функції та функціонування як системи.

Специфіка дослідження функцій кримінально-правової політики полягає ще й у тому, що ці функції та результати їх реалізації відбиваються в реальному житті, що, зі свого боку, зумовлює необхідність використання соціологічного підходу, адже саме соиіологічні методи можуть відобразити сприйняття й оцінку кримінально-правової 
політики суспільством, а також вести мову про ефективність реалізації ії функцій, наприклад, через правозастосування. Про це вів мову В. М. Кудрявцев, говорячи про те, що співвідношення, взаємозв' язок і взаємодія права, його інститутів і норм із соціальною дійсністю є центральною проблемою соціології права, адже вона розкривається за двома напрямками: соціальна обумовленість права і соціальна ефективність права [11] . Цілком зрозуміло, що питання взаємодії кримінально-правової політики з суспільством, проблеми соціальної обумовленості та соціальної ефективності функцій кримінально-правової політики входять до будь-яких досліджень кримінально-правової політики, тому використання соціологічних методів $€$ неминучим.

Як стверджують автори монографії щодо методології дослідження державної політики та ії сфер, застосування нових методологічних підходів у дослідженні державних політик створює можливості для усвідомлення (чи розкриття) нових, раніше прихованих його властивостей, характерних особливостей тощо, що і $є$ подальшим кроком у науковому пізнанні [2, с. 10-11]. Серед таких методів вони виділяють інституиіональний метод [2, с. 11], який є відносно новим у науці, i, очевидно, абсолютно новим у дослідженні функцій кримінально-правової політики.

Інституціональний підхід конщентрується на описі формальних та юридичних аспектів діяльності суб'єктів кримінально-правової політики. Саме за допомогою цього методу досліджується інституційне (суб'єктне) та нормативне (у плані визначення компетенщії) наповнення функціонування кримінально-правової політики як механізму. Як зазначають у літературі, інституціональна теорія в методологічному плані допомагає зрозуміти процес політики через систему контролю і врівноваження та розмежування гілок влади згідно з Конституцією. Державним інститутам надаються певні повноваження і функщіі, які допомагають визначити майбутні дії кожного інституту [2, с. 39]. Інституціональний підхід надає можливість вести мову про кримінально-правову політику як політичну систему, що володіє певними функціями. У межах цієї системи і відбувається процес прийняття владно-політичних рішень, результатом яких є відповідні кримінально-правові норми. Важливість цього підходу зумовлена тим, що владні структури є структурованими моделями індивідуальної та групової поведінки, які тією чи іншою мірою впливають на зміст державної політики, а особливо - політики у сфері протидії злочинності. Дослідники методології вивчення державних політик наводять цікавий приклад застосування інституційного методу для визначення впливу суб'єкта на формування чи реалізацію функцій державної політики: «...іншим оригінальним інститутом, крізь призму якого можна осмислити феномен радянського тоталітаризму, є «Ради». Завдяки оригінальному погляду на ідею поділу влади, партія зберігала політичну владу, але не брала на себе відповідальність за поточні справи. Водночас через систему рад диктатура заглиблювалася в народні низи» [2, с. 66]. На дещо інші аспекти інституційного методу, а саме в контексті інституціоналізації нормативності кримінального права, вказує С. М. Вечерова [12, с. 90-92]. І хоча вчена говорить про «позитивне кримінальне право», що, звичайно, лише дотикається питань функціонування кримінально-правової політики, однак їі розвідки свідчать про все частіше застосування пропонованого (раніше не притаманного для кримінально-правових досліджень) методу.

Не можна не згадати також специфіку порівняльн-правового (компаративістсъкого) методу. Запозичення світового досвіду протидії злочинності, без сумнівів, має 
надзвичайно важливе значення для побудови нащіональних стратегій у рамках кримінально-правової політики. Однак, до такого запозичення слід ставитися дуже обережно, адже не все те, що добре працює «там», буде ефективно працювати «тут». Як зазначає А. Ф. Степанюк, наприклад, «іноземна форма (в'язнищі мінімального, середнього і максимального рівня безпеки) була приєднана до вітчизняного змісту діяльності системи виправних колоній у результаті політичного рішення. Помилковість такого рішення визначається тим, що форма не може бути приєднана до змісту якимось зовнішнім чином, а має бути продуктом саморозвитку змісту. ... Запозичення лише іноземної назви, без врахування того, що за кордоном функціонують саме в' язнищі, а не виправні колонії радянського зразка, без зміни змісту (створення в' язниць як установ, деповодження із засудженими має метою надання їм соціальної допомоги для полегшення реінтегращії в суспільство після закінчення строку покарання) виявилось безплідним через свою схоластичність, відірваність від практики» [13, с. 358].

Висновки. Отож, незважаючи на плюралізм методів у сучасній кримінальноправовій науці, дослідження функцій кримінально-правової політики має обумовлену вище специфіку, що пояснює необхідність обрання для отримання позитивних результатів належних загальнонаукових та спеціально-галузевих методів наукових досліджень.

\section{Використані джерела:}

1. Юридична енциклопедія: В 6 т. /Редкол.: Ю. С. Шемшученко (голова редкол.) та ін. К.: «Укр. енщикл.», 1998.). Т. 3.

2. Дослідження державних політик: методологія, процедури та європейські практики: монографія / авт. кол.: [Л. В. Гонюкова, В. М. Козаков, В. А. Ребкало та ін.]; за заг. ред. Л. В. Гонюкової, В. М. Козакова. Київ: НАДУ, 2018.

3. Рябчинська О. П. Методологія досліджень проблем кримінального права: постановка проблеми. Право і Безпека. 2013. № 1. С. 157-163.

4. Демидова Л. М. Кримінальне право в загальній системі наукових знань: методологічний аспект кримінально-правових досліджень. Юридичний вісник. № 3 (36), 2015. С. 139-143.

5. Козич I. В. Кримінально-правова політика в сфері протидії злочинам, що вчиняються із застосуванням насильства: дис. канд.юрид.наук. 12.00.08. Львів: ЛьвДУВС, 2012. 214 c.

6. Панов М. І. Основи методології науки кримінального права. Вісник Асоціації кримінального права України. 2017. № 2(9). URL: http://vakp.nlu.edu. ua/article/view/ 165680/ 165048 (дата звернення 10.01.2020).

7. Горбань В. С. Влияние философии Гегеля на формирование и развитие учения о праве Иеринга (начало). Право и политика. 2017. № 5. С. 77-97. URL: https://nbpublish. com/ library_read_article.php?id=22214.

8. Пехник А. В. Теоретико-методологічні основи дослідження політичного управління як системи. Актуальні проблеми держави і права. 2004. № 22 (82).

9. Фріс П. Л. Вибрані праці. Івано-Франківськ: Фоліант, 2014.

10. Фріс П. Л., Савінова Н. А. Моделювання у кримінально-правовій політищі. Наме право. 2017. № 2. С. 113-118.

11. Кудрявцев В. Н. Право и социальная действительность / В сб.: Проблемы социологии права. Вильнюс, 1970. Вып. 1. С. 7-14. 
12. Вечерова Є. М. Інституціоналізащя нормативності кримінального права: окремі теоретико-методологічні аспекти питання. Науковий Вісник Міжнародного гуманітарного університету. Сер.: Юриспрудениіл. 2017. № 27. С. 90-92.

13. Степанюк А. Ф. Рівні безпеки виправних колоній. Кримінальне право в умовах глобалізації суспільних процесів: традиції та новації: матеріали міжнар. наук.-практ. круглого столу, м. Харкіb, 15 трав. 2020 р. / [редкол.: В. Я. Тацій (голов. ред.), Л. М. Демидова (заст. голов. ред.), А. П. Гетьман та ін.]. Харків: Право, 2020. С. 358.

\section{References:}

1. Yurydychna entsyklopediia. (1998) (Vol.1-6; vol. 3.) Yu. S. Shemshuchenko (Ed.) et al. Kyiv: «Ukr. Entsykl». [in Ukrainian].

2. Doslidzhennia derzhavnykh polityk: metodolohiia, protsedury ta yevropeiski praktyky: monohrafiia. (2018) L. V. Honiukova, V. M. Kozakov, V. A. Rebkalo (Eds.) et al.; L. V. Honiukova, \& V. M. (Eds.) Kyiv: NADU. [in Ukrainian].

3. Riabchynska, O. P. (2013) Metodolohiia doslidzhen problem kryminalnoho prava: postanovka problemy. Pravo i Bezpeka-Law and Security, 1, 157-163. [in Ukrainian].

4. Demydova, L. M. (2015) Kryminalne pravo v zahalnii systemi naukovykh znan: metodolohichnyi aspekt kryminalno-pravovykh doslidzhen. Yurydychnyi visnyk-Legal Bulletin, 3 (36), 139-143. [in Ukrainian].

5. Kozych, I. V. (2012) Kryminalno-pravova polityka v sferi protydii zlochynam, shcho vchyniaiutsia iz zastosuvanniam nasylstva. Candidate's thesis. LvDUVS. [in Ukrainian].

6. Panov, M. I. (2017) Osnovy metodolohii nauky kryminalnoho prava. Visnyk Asotsiatsii kryminalnoho prava Ukrainy - Bulletin of the Association of Criminal Law of Ukraine, 2(9). URL: http:/ / vakp.nlu.edu.ua/article/view/165680/165048. [in Ukrainian].

7. Horban, V. S. (2017) Vlyianye fylosofyy Hehelia na formyrovanye y razvytye uchenyia o prave Yerynha (nachalo). Pravo y polytyka- Law and politics, 5, 77-97. URL: https://nbpublish. com/library_read_article.php?id=22214. [in Ukrainian].

8. Pekhnyk, A. V. (2004) Teoretyko-metodolohichni osnovy doslidzhennia politychnoho upravlinnia yak systemy. Aktualni problemy derzhavy i prava-Current issues of state and law, 22 (82). [in Ukrainian].

9. Fris, P. L. (2014) Vybrani pratsi. Ivano-Frankivsk: Foliant. [in Ukrainian].

10. Fris, P. L., Savinova, N. A. (2017) Modeliuvannia u kryminalno-pravovii politytsi. Nashe pravo- Our right, 2, 113-118. [in Ukrainian].

11. Kudriavtsev, V. N. (1970) Pravo y sotsyalnaia deistvytelnost. Problemy sotsyolohyy pravaProblems of sociology of law, issue 1, 7-14. Vylnius. [in Ukrainian].

12. Vecherov, Ye. M. (2017) Instytutsionalizashchia normatyvnosti kryminalnoho prava: okremi teoretyko-metodolohichni aspekty pytannia. Naukoryi visnyk Mizhnarodnoho humanitarnoho universytetu. Ser.: Yurysprudentsiia- Scientific Bulletin of the International Humanities University. Ser.: Jurisprudence, 27, 90-92. [in Ukrainian].

13. Stepaniuk, A. F. (2020) Rivni bezpeky vypravnykh kolonii. Kryminalne pravo v umovakh hlobalizatsii suspilnykh protsesiv: tradytsii ta novatsii: materialy mizhnar. nauk.-prakt. kruhloho stolu, $m$. Kharkiv, 15 trav. 2020 r.- Criminal law in the context of globalization of social processes: traditions and innovations: materials intern. scientific-practical round table, Kharkiv, May 15. 2020. V. Ya. Tatsii (Ed.), L. M. Demydova (Eds.), A. P. Hetman et al. Kharkiv: Pravo, 358. [in Ukrainian]. 
Козич И. В,

кандидат юридических наук, доцент, доцент кафедры уголовного права учебно-научного юридического института ГВУз «Прикарпатский национальный университет

имени В. Стефаника»

(г. Ивано-Франковск, Украина)

\section{МЕТОДЫ ИССЛЕДОВАНИЯ УГОЛОВНО-ПРАВОВОЙ ПОЛИТИКИ И ЕЕ ФУНКЦИЙ}

Любое научное исследование в области юриспруденции, как правило, начинается с формулировки и определения научной проблемы, которая подлежит решению в процессе исследования. Однако самого понимания проблемы, определения ее объекта и предмета явно недостаточно, ведь каждый ученый, осознав эти вопросы и определив для себя подходящую цель и задачи, сталкивается с необходимостью выбора методов исследования, которые, на его взгляд, являются наиболее эффективными для решения той или иной задачи.

Это обязательная составляющая современного научного исследования, которая определяет дальнейшие способы получения эмпирического материала и его обработки для достижения оправданных и научно обоснованных результатов.

В статье автор рассматривает особенности применения общенаучных, групповых и специально-научных методов, исходя из специфики исследования уголовно-правовой политики и ее функций.

Ключевые слова: политика в сфере борьбы с преступностью, уголовно-правовая политика, функции политики в сфере борьбы с преступностью, функции уголовно-правовой политики, методы научного исследования.

\section{Kozych I., \\ Candidate of Law, Associate Professor, Associate Professor of Criminal Law educational and scientific legal Institute of higher educational Institutions \\ "V. Stefanyk Precarpathian National University" (Ivano-Frankivsk, Ukraine)}

\section{METHODS OF RESEARCH OF CRIMINAL LAW POLICY AND ITS FUNCTIONS}

Any scientific exploration in the field of jurisprudence usually begins with the formulation and delineation of a scientific problem to be solved in the research process. However, the very understanding of the problem, the definition of its object and subject, is clearly not enough, because every scientist, realizing these issues and defining the appropriate purpose and objectives, is faced with the need to choose research methods that, in his opinion, are most effective of a task.

This is a mandatory component of modern scientific research, which identifies further ways to obtain empirical material and its processing to achieve justified and scientifically sound results. 
In the article the author considers the peculiarities of the application of general scientific, group and special scientific methods, based on the specifics of the study of criminal law policy and its functions.

Methodological bases as a result of connection of the ways of cognitive activity recommended by it with available knowledge are unity of the subject theory and methods of its development and introduction. This system includes as a mandatory element the basic theoretical provisions of the worldview. They determine the direction of the study of criminal law phenomena, their boundaries and relationships with related legal phenomena, which seems particularly relevant in the context of studying the problems of criminal law policy.

The correct understanding of the essence and role of any criminal law theories in the study of criminal law phenomena can be achieved only taking into account many interrelated factors, among them the determinants are: a) features of reflection in the theory of the real state of affairs; b) the connection of criminal law theory with law enforcement; c) features of the theory and its dynamics. This involves the widespread use of tools and methods of logic and methodology of science to analyze the structure of criminal law theories, the role of empirical and theoretical concepts in the systematization of scientific knowledge on the problem, as well as to theoretically explain and predict the development of criminal law phenomena. The author concludes that it is virtually impossible to investigate the functions of criminal law policy without defining a theoretical understanding of its functional model with access to its actual functioning.

Keywords: policy in the field of crime control, criminal law policy, functions of policy in the field of crime control, functions of criminal law policy, research methods.

DOI: $10.33766 / 2524-0323.90 .49-58$

УДК 342.9

Н. П. Костюк,

старший викладач кафедри права

Вінницького торговельно-економічного інституту КНТЕУ

(м. Вінниця, Україна)

e-mail: kostuknatalia5@gmail.com

iD ttps:/ / orcid.org/0000-0001-5272-982X

\section{ПРАВОВИЙ РЕЖИМ ТА ОЗНАКИ НАДЗВИЧАЙНОГО СТАНУ В УКРАЇНІ}

У статті досліджується правовий режим та ознаки надзвичайного стану в Україні, обмеження, які можуть бути застосовані до громадян при введенні надзвичайного стану; визначаються особливості правового статусу органів державної влади і місцевого самоврядування під час надзвичайного стану. Запропоновано вдосконалити законодавчу базу, яка регулює правовий режим надзвичайного стану й закріпити чіткий алгоритм дій для органів державної влади і місцевого самоврядування в разі введення надзвичайного стану. Наголошено на запозиченні позитивного досвіду закордонних країн, які передбачили в законодавстві завчасне правове регулювання основних питань запровадження й підтримання надзвичайного стану.

Ключові слова: надзвичайний стан, ознаки надзвичайного стану, гарантії законності в умовах надзвичайного стану, надзвичайна ситуація природного характеру, надзвичайна ситуація техногенного характеру.

(C) Костюк Н. П., 2020 